\title{
A Great Tit Parus major without yellow pigment in its plumage
}

\author{
En talgoxe Parus major utan gult pigment i fjäderdräkten
}

\author{
SÖREN SVENSSON \& GERMUND KADIN
}

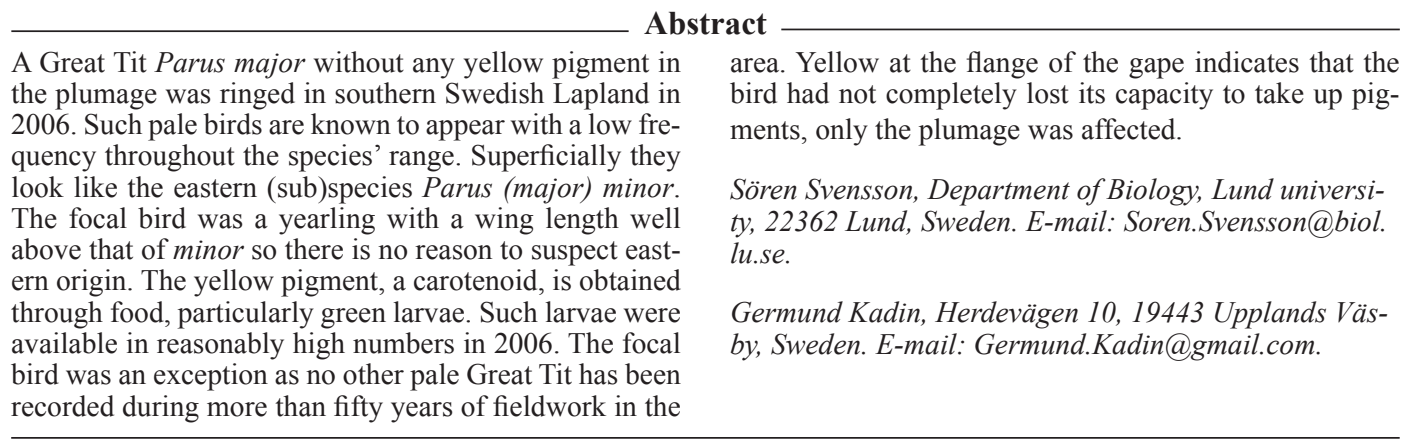

Received 30 September 2018, Accepted 16 October 2018, Editor: Robert Ekblom

On 22 July 2006, we were trapping and ringing birds at Ammarnäs in southern Swedish Lapland. At 10:40 hrs we got a yearling Great Tit Parus major with a plumage that was white where normal Great Tits are yellow and grey to bluish where normal birds are greenish. The bird was photographed both in natural sunlight below green canopy and with flashlight (Figure 1). In certain angles one could sense a tinge of greenish colour (possibly seen in the upper photo) but it was difficult to tell whether this was a result of true presence of pigment or only light refraction in the feathers or reflection caused by the strong sunshine though the intensively green canopy. In other angles and in the photos with flashlight we were not certain about whether any green at all could be seen. The only body part that showed yellow colour was the gape, most clearly seen on the swollen flange of the gape in the lower photo. Birds have been trapped in July and August every year since 1983 at this site which is located at $66^{\circ} \mathrm{N}$ and $16^{\circ} \mathrm{E}$, about six kilometres west of Ammarnäs, adjacent to the stream Tjulån and the lake Tjulträsk, in birch woodland at an elevation of $540 \mathrm{~m}$. The Great Tit is a regularly breeding species in the area, with a mean density of 1.4 territories $/ \mathrm{km}^{2}$ (Enemar et al. 2004). At the ringing site a total of 235 birds had been ringed and examined through 2015. The average annual number of ringed Great Tits is seven with a range from zero in
1999 to 29 in 1986 . In 2006 the bag was 14 birds which was the third best year. There is no previous record of a pale Great Tit at the site.

The yellow colour of Great Tits is known to vary much, at least with habitat, year, sex, age, and hatch-date (Slagsvold \& Lifjeld 1985). The yellow colour depends on pigments of the carotenoid group, betacarotene, lutein and zeaxanthin. These pigments cannot be synthesised by the birds themselves. They have to obtain them through food, primarily by eating green larvae. Partali et al. (1987) studied the transport from plant to bird in the Great Tit and found that the pigments were resorbed unchanged by the larvae and further that no modification occurred in the tits. All three pigments were deposited in the eggs but only lutein and xanthin in the feathers. In the area where the pale bird was trapped the predominant larvae are Epirrita autumnata and Operophtera sp. (Enemar et al. 2004). These species are irruptive, extremely abundant in certain years and almost absent in other years. In the particular year of 2006 their numbers were low but not extremely low. It is unlikely that the Great Tits would not be able to obtain sufficient amounts of carotenoids, and no other bird than the focal one showed a pale plumage.

The measurements of the focal bird were within normal range for juveniles at this site and time of year. The wing length was $79 \mathrm{~mm}$. Average value 

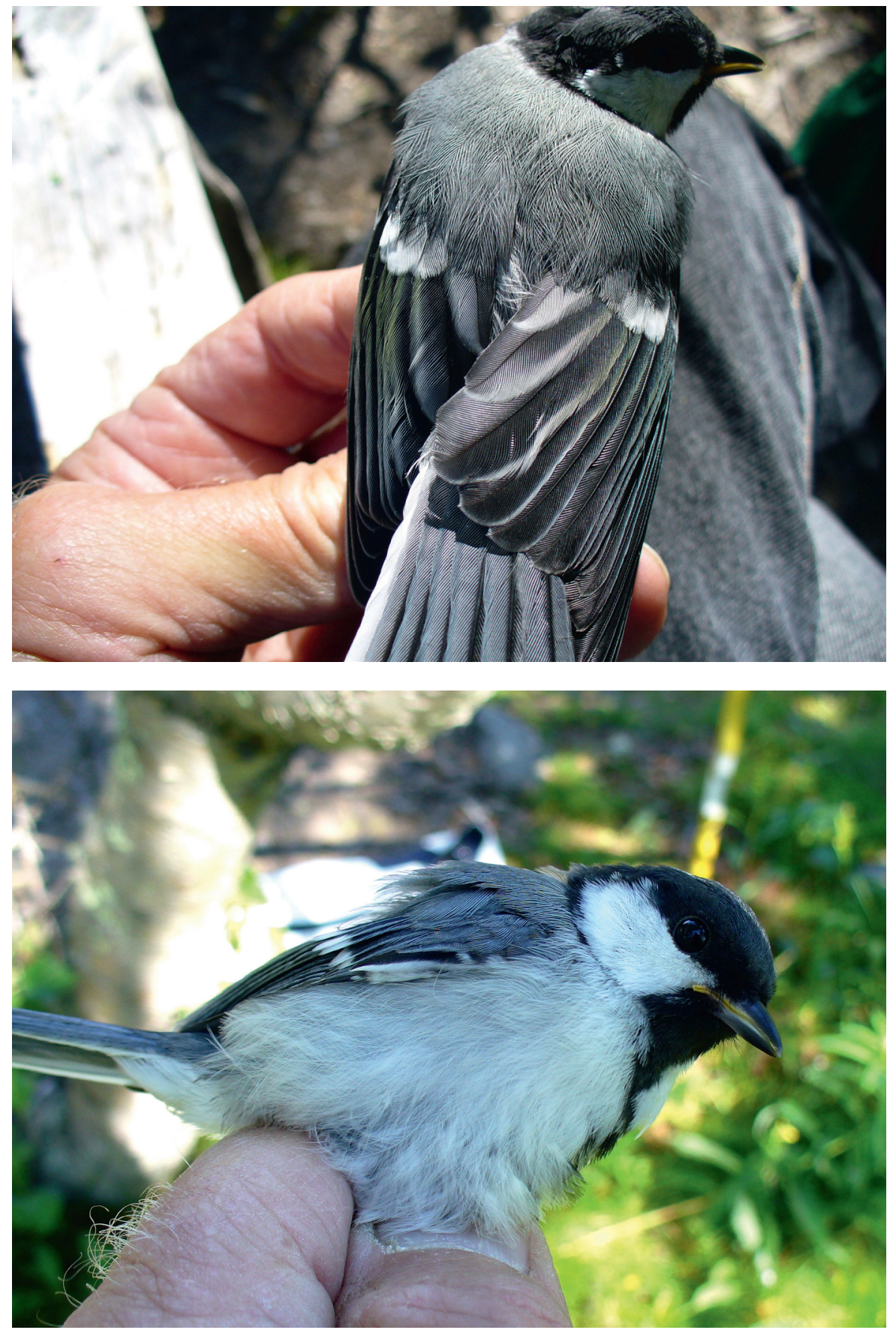

Figure 1. Great Tit without yellow pigment in the plumage. Upper photo in natural sunlight below green canopy. Some green tinge may be observed on the edges of the primaries, but it is difficult to tell whether it is a result of refraction or reflection of the canopy colour. No green can be observed in the lower photo which was taken with flashlight.

Talgoxe utan gult pigment i fjäderdräkten. Det övre fotot i naturligt solljus under grönt krontak. Grön anstrykning på handpennornas kanter kan kanske ses, men det är svårt att avgöra om det är resultat av refraktion eller reflektion på grund av bladverket. Inget grön kan ses på det undre fotot som togs med blixt. 
of 112 juveniles was $77.1 \mathrm{~mm}$ ( $\mathrm{sd}=1.96$; range 72 82). The weight was $16.3 \mathrm{~g}$. Average weight of 157 juveniles was $17.1 \mathrm{~g}$ ( $\mathrm{sd}=1.08$; range $14.1-19.8)$. The bird may have been a male as its wing length was equal to the average of 24 adult males (78.7; range $76-83 \mathrm{~mm}$ ) but at the very upper range limit of 34 adult females $(75.1$; range $70-79 \mathrm{~mm}$ ) that had been measured at the same site.

The frequency of pale Great Tits in Sweden is low. In the photo documentation of bird records at the Swedish Species Gateway (Artportalen.se) there are four pale individuals among 2219 photos of Great Tits (through 26 August 2018). These four individuals were photographed on 18 October 2007 (by Kalle Brinell at Enskär, Hartsö Skärgård, Sörmland), 16 January 2011 (by Jonas Svensson at Malung, Dalarna), 5 March 2012 (by Andreas Pettersson at Tylösand, Halland) and 2 February 2014 (by Patrik Wildjang at Östra Bröta, Sörmland). (A fifth photo of a pale individual on 21 January 2018 by Mats Havskogen at Malmö, Scania, is not considered here as some greenish can be seen and there is no comment about its appearance). In the four cases there are comments that confirm the impression given by the photos that there was really no yellow pigment. The comments included speculation about eastern origin or similarity with the minor type of Great Tits. The four birds were represented by together 13 photos, which is $0.59 \%$ of all Great Tit photos. However, this proportion is likely to be far from correct as photographs of birds that are particular in some sense are published more often than birds of average look. It is therefore likely that the true proportion is much lower. An unbiased proportion ought to be obtained from bird ringing stations. At two Swedish ringing sites (Ottenby Bird Observatory and Falsterbo Bird Observatory) an average of about one thousand Great Tits are examined every year (Karlsson et al. 2005). I have asked the directors of these observatories (Magnus Hellström, Ottenby and Lennart Karlsson, Falsterbo) about how often they encounter Great Tits without any yellow pigment in the plumage. Both replied that they could not recall any such case. It is of course difficult to judge if the proportion has been exactly zero as over the many years of records different ringers have been involved. As there have been no explicit instructions to report pale Great Tits, such individuals may have been handled without documentation of the aberration. But it can be concluded that the proportion must be extremely low.

Being antioxidants, carotenoids are assumed to play a role for the health and vitality of birds. The degree of plumage yellowness has been found to correlate with several factors, for example immune competence (Dufva \& Allander 1995), nutritional condition (Senar et al. 2003) including those of nestlings (Hõrak et al. 2000), and parasite load (Hõrak et al. 2001). It correlates also with environmental stress (Isaksson et al. 2005). Hence it may serve as a general index of health (e.g. Ots et al. 1998). One form of environmental stress is exposure to pollutants. Eeva et al. $(1998,2008)$ found that both the intensity of yellow pigmentation as well as the number of green larvae increased with the distance from a pollution source. These studies were made on birds with natural variation of their colours and did not involve birds without yellow pigment.

The focal bird seems to be similar to the eastern subspecies or species of the Parus major complex (such as minor; Kvist et al. 2003, Päckert et al. 2005). But the bird had a wing length well above that of the smaller eastern birds. As the bird was quite young it must have been of local origin. Hence there is no reason to look into the possibility of anything but a local aberration, such as a mutation or other deficiency related to carotenoid uptake or allocation. The yellow flange of the gape indicated that the bird had not completely lost its capability to take up yellow pigment.

\section{Acknowledgement}

Åke Lindström provided the data on ringed and measured Great Tits at Ammarnäs.

\section{References}

Dufva, R. \& Allander, K. 1995. Intraspecific variation in plumage coloration reflects immune response in great tit (Parus major) males. Functional Ecology 9(5): 785-789.

Eeva, T., Lehikoinen, E. \& Rönka, M. 1998. Air pollution fades the plumage of the Great Tit. Functional Ecology 12: 607-612.

Eeva, T., Sillanpää, S., Salminen, J.-P., Nikkinen, L., Tuominen, A., Toivonen, E., Pihlaja, K. \& Lehikoinen, E. 2008. Environmental pollution affects the plumage color of Great Tit nestlings through carotenoid availability. EcoHealth 5: 328-337.

Enemar, A., Sjöstrand, B., Andersson, G. \& von Proschwitz, T. 2004. The 37-year dynamics of a subalpine passerine bird community, with special emphasis on the influence of environmental temperature and Epirrita autumnata cycles. Ornis Svecica 14: 63-106.

Hõrak, P., Velllau, H., Ots, I. \& Møller, A.P. 2000. Growth conditions affect carotenoid-based plumage coloration of great tit nestlings. Naturwissenschaften 87(10): 460-464.

Hõrak, P., Ots, I., Vellau, H., Spottiswoode, C. \& Møller, A.P. 2001. Carotenoid-based plumage coloration reflects 
hemoparasite infection and local survival in breeding great tits. Oecologia 126(2) :166-173.

Isaksson, C., Örnborg, J., Stephensen, E. \& Andersson, A. 2005. Plasma glutathione and carotenoid coloration as potential biomarkers of environmental stress in great tits. EcoHealth 2(2) :138-146.

Karlsson, L., Ehnbom, S. \& Walinder, G. 2005. A comparison between ringing totals at Falsterbo, SW Sweden, ringing totals at Ottenby, SE Sweden, and point counts from the Swedish Breeding Bird Census during 20 years (1980-1999). Ornis Svecica 15: 183-205.

Kvist, L., Martens, J., Higuchi, H., Nazarenko, A., Valchuk, O. \& Orell, M. 2003. Evolution and genetic structure of the great tit (Parus major) complex. Proceedings of the Royal Society B 207 (1523): 1447-1454.

Ots, I., Murumägi, A. \& Hõrak, P. 1998. Haematological health state indices of reproducing Great Tits: methodology and sources of natural variation. Functional Ecology 12: 700-707.

Päckert, M., Martens, J., Eck, S., Nazarenko, A.A.; Valchuk, O.P., Petri, B. \& Veith, M. 2005. The great tit (Parus major) - a misclassified ring species. Biological Journal of the Linnean Society 86 (2): 153-174.

Partali, V., LIaaen,-Jensen, S., Slagsvold, T. \& Lifjeld, J.T. 1987. Carotenoids in food chain studies-II. The food chain of Parus spp. Monitored by carotenoid analysis. Comparative Biochemistry and Physiology Part B: Comparative Biochemistry 87(4): 885-888.

Senar, J.C., Figuerola, J. \& Domènech, J. 2003. Plumage coloration and nutritional condition in the great tit Parus major: the roles of carotenoids and melanins differ. Naturwissenschaften 90(5): 234-237.

Slagsvold, T. \& Lifjeld, J.T. 1985. Variation in plumage colour of the Great tit Parus major in relation to habitat, season and food. J. Zool., Lond. (A) 206: 321-328.

\section{Sammanfattning}

Vid ringmärkning i Ammarnäs i södra Lappland i juli 2006 fångade vi en talgoxe som helt saknade gul färg i fjäderdräkten. Där vanliga talgoxar är gula var denna fågel vit och där de är grönaktiga var denna fågel gråblå. Gul färg fanns endast i gapet, vilket syns på den svullna delen längst in i näbbgipen på ett av fotona. Fågeln ringmärktes, vägdes och mättes. Den fotograferades i såväl naturligt solljus som med blixt (Figur 1). Fågeln liknade således den östliga formen av talgoxe som om den ges artstatus kallas Parus minor. Den aktuella fågelns mått, vinglängd $79 \mathrm{~mm}$ och vikt $16.3 \mathrm{~g}$, ligger dock helt inom det normala för vanlig talgoxe men över vad som gäller för östlig talgoxe. Detta i kombination med att det var en ungfågel visar på lokalt och utesluter östligt ursprung. I bildarkivet hos Artportalen.se kan man hitta foton på fyra talgoxar som är bleka på samma sätt som fågeln i Ammarnäs. Det är dock svårt att från detta beräkna hur stor andel av talgoxarna som kan sakna gult pigment i fjäderdräkten eftersom avvikande individer sannolikt publiceras i större utsträckning än fåglar med normalt utseende. På förfrågan har jag fătt besked om att man inte registrerat några fåglar utan gul färg vare sig vid Ottenby eller vid Falsterbo fågelstationer där tusentals talgoxar ringmärkts. Frekvensen måste därför vara synnerligen låg.

Talgoxarnas gula färg beror på karotenoider. Dessa pigment kan fåglarna inte syntetisera själva utan måste ta in via födan, i första hand gröna larver. Pigmenten, som är antioxidanter, anses ha många olika funktioner för fåglarnas hälsa och vitalitet. Den gula färgens intensitet anses därför också kunna användas som indikator på en fågels hälsotillstånd, t.ex. immunförsvarets status eller parasitbelastning. Man har också funnit att det finns samband mellan graden av gulhet och miljöföroreningar. I dessa studier är det dock fråga om grader av gulhet, inte om avsaknad av gult pigment. I det aktuella fallet behöver man inte spekulera om brist på gröna larver eller föroreningar som orsak, utan observationen är säkerligen resultat av en mutation eller någon sjuklig förändring i ämnesomsättningen. Man måste dock notera att det fanns gult pigment $\mathrm{i}$ fågelns gap, vilket indikerar att förmågan att ta upp pigment inte hade förlorats helt, utan bara drabbat fjäderdräkten. 